\title{
Urbanization does not affect green space bird species richness in a mid-sized city
}

\author{
Dávid Korányi ${ }^{1,2}$ (D) $\cdot$ Róbert Gallé $^{1}$ (D) B Bettina Donkó ${ }^{3} \cdot$ Dan E. Chamberlain ${ }^{4}$ (D) Péter Batáry ${ }^{1,3}$ (D)
}

Accepted: 1 December 2020 / Published online: 10 December 2020

(C) The Author(s) 2020

\begin{abstract}
Urbanization is one of the most intensive forms of landscape and habitat transformation, resulting in species loss, and taxonomic and functional homogenization of different communities. Whilst green infrastructure (the network of natural and semi-natural areas in cities) has been studied extensively in terms of specific features that promote biodiversity, there have been no studies that have assessed how species richness in different types of green space (GS) varies with increasing levels of urbanization in the surrounding matrix. We studied the effects of different types of GS and urbanization in the surrounding matrix on bird communities in the mid-sized city of Göttingen, Germany. We used the point-count method for bird observations in allotments and parks. To determine the level of urbanization, we calculated percentage of impervious surfaces around GSs. Increasing levels of urbanization around GSs had no effect on the species richness, functional traits or the community composition of birds. Nevertheless, we found that species richness and functional traits varied according to GS type. Parks had a greater species richness and were found to have more ground nesting and tropical migrant birds compared to allotments. We found more cavity nesting and resident birds in allotments. As different types of GS can contribute to the presence of different species and functional trait variations, their positive effect on bird species richness can be enhanced when they are present together in urban landscapes. Our findings suggest that green spaces with a high variety of local characteristics should be incorporated into urban planning designs in order to ensure diverse bird communities in cities.
\end{abstract}

Keywords Allotment $\cdot$ Community composition $\cdot$ CWM $\cdot$ Functional trait $\cdot$ Landscape $\cdot$ Park

\section{Introduction}

Today more than half of the world's population lives in cities and this proportion is expected to increase to $66 \%$ by 2050 (United Nations 2014). In addition, urban land cover is predicted to increase by 1.2 million $\mathrm{km}^{2}$ in the first 30 years of the twenty-first century (Seto et al. 2012). Urbanization is considered as one of the most extreme forms of landscape

Péter Batáry

batary.peter@okologia.mta.hu

1 Centre for Ecological Research, Institute of Ecology and Botany, "Lendület" Landscape and Conservation Ecology, Alkotmány u. 2-4, Vácrátót 2163, Hungary

2 Centre for Ecological Research, GINOP Sustainable Ecosystems Group, Klebelsberg Kuno utca 3, Tihany 8237, Hungary

3 University of Goettingen, Agroecology, Grisebachstr. 6, 37077 Göttingen, Germany

4 Department of Life Sciences and Systems Biology, University of Torino, Via Accademia Albertina 13, 10123 Torino, Italy transformation and thereby has the greatest local effect on wildlife (Marzluff and Ewing 2001). Urbanization-induced habitat loss and fragmentation leads to reduced populations of native plants, decreased connectivity between vegetation patches (Williams et al. 2005; Parsons et al. 2019) and changed environmental conditions, such as altered microclimate and air pollution (Grimm et al. 2008). Consequently, by replacing natural or semi-natural habitats, cities are considered as one of the leading threats to biodiversity (Czech et al. 2000). Understanding how to accommodate a growing human population in cities whilst minimizing the negative impacts of urbanization is therefore a major challenge (United Nations 2018).

The negative impact of urbanization on wildlife has been demonstrated frequently. There is a general trend for species richness to decline with increasing levels of urbanization for arthropods, amphibians, mammals and reptiles (McKinney 2008). Urbanization also leads to a reduction in avian species richness (Clergeau et al. 2001; Batáry et al. 2018). For example, Clergeau et al. (2006) showed that species richness in city centers is less than half that in non-urban areas. However, bird 
density is generally higher in urbanized areas, but only a few, urban tolerant species contribute to this increase (Clergeau et al. 2006; Ortega-Álvarez and MacGregor-Fors 2009; Conole and Kirkpatrick 2011).

Bird species can be categorized as urban avoiders, adapters and exploiters depending on their ability to tolerate urban disturbance and utilize the resources provided by cities (Geschke et al. 2018). Species in these categories differ in their functional traits such as feeding, migratory and nesting behavior, which are decisive in adapting to urban environments (Kark et al. 2007; Evans et al. 2011; Máthé and Batáry 2015). Hence, urbanization can be considered as an environmental filter, which results in functionally similar bird communities (Croci et al. 2008; Meffert and Dziock 2013). Urban avoiders are generally adapted to woody habitats and they are mostly tree foraging and insectivorous species. Among these, tropical migrants are frequent, as are ground nesters. In contrast, urban adapters and exploiters have better capability to use human-related resources and often breed successfully on artificial structures, such as buildings, in highly urbanized areas (MacGregor-Fors and Schondube 2011). These species are mostly resident, nesting higher in trees, and their diet predominantly consists of seeds and other plant material, or they have a mixed diet (Chace and Walsh 2006; Kark et al. 2007; Croci et al. 2008). Other traits such as body mass may also be associated with urbanization. Despite some contradictory results reported in the literature (Garden et al. 2006; Conole and Kirkpatrick 2011), the bird community is generally dominated by larger species in more urbanized areas (Kark et al. 2007; Croci et al. 2008; Chamberlain et al. 2017).

Green spaces embedded in an urban matrix (e.g. gardens, parks, woodlots, and cemeteries) play an important role in providing corridors to link fragmented habitats and maintaining the remaining original biological diversity (FernándezJuricic and Jokimäki 2001; Tryjanowski et al. 2017; Callaghan et al. 2019). Moreover, these landscape elements in cities can contribute to the mitigation of functional homogenization in avian communities by offering a wider spectrum of food resources for granivores and insectivores and providing shelter where human disturbance is lower than in other urban areas (Ortega-Álvarez and MacGregor-Fors 2009). However, the magnitude of the mitigation effect may vary depending on the characteristics of green spaces, such as management, cultivated and natural forms of vegetation, or even shrub and tree cover, which provides additional habitat complexity, nesting sites and feeding resources for birds (MacGregor-Fors and Schondube 2011; Chong et al. 2014; Paker et al. 2014; Taylor et al. 2016). Bird communities are also affected by the size of green spaces. Bird species richness is positively related to size of green spaces (Chamberlain et al. 2007a; Callaghan et al. 2018; Mayorga et al. 2020; Pirzio Biroli et al. 2020), and large expanses of these green infrastructure elements allow the occurrence of less disturbance- tolerant species in urban landscapes (Fernández-Juricic and Jokimäki 2001; Kohut et al. 2009; Carbó-Ramírez and Zuria 2011).

Among green spaces, parks are more or less extensive areas, which provide important recreational, environmental and cultural services for humans. They are heterogeneous green habitats in urban ecosystems that shows high vegetation diversity and microhabitat heterogeneity (Fernández-Juricic and Jokimäki 2001; Shwartz et al. 2008). Parks are among the most species rich types of urban green space for many taxonomic groups (Nielsen et al. 2014) and often contain more bird species than other types of urban green space (CarbóRamírez and Zuria 2011; Nielsen et al. 2014; Barth et al. 2015). Allotments (i.e. municipal areas, usually spatially separated from housing, that are used for small scale fruit and vegetable production) are also common features in many cities. Despite that allotments have differing objectives (i.e. food production) and hence differing management regimes, they nevertheless share some features with public parks. For example, they are known to be hot-spots for pollinators (Baldock et al. 2019), can hold a high diversity of plant species (Speak et al. 2015; Borysiak et al. 2017) and can maintain higher soil quality than nearby intensive agriculture (Edmondson et al. 2014). Although allotments may be important for individual bird species (e.g. house sparrow Passer domesticus; Chamberlain et al. 2007b), there is yet no evidence as to how they contribute to wider species richness in urban areas (Quesada and MacGregor-Fors 2010). Furthermore, the response of avian species richness to the urban matrix in allotments, and how this compares to other types of green space, has not been considered (Filazzola et al. 2019).

In this study, we examined species richness, functional traits and community composition of bird communities in two different types of GS, allotments and parks along an urbanization gradient (measured as increasing percentage of impervious surfaces). Our aim was to determine the extent to which urbanization in the surrounding matrix affects the species richness of green infrastructure, and whether different types of green space respond in the same way to urbanization. More specifically, we had the following expectations:

1. The species richness of the bird community, and

2 . the number of birds with urban avoider characteristics decrease in GSs with increasing level of urbanization of the matrix.

3. Bird species richness and number of birds with urban avoider characteristics increase with increasing GS size.

4. Parks and allotments support different species and bird communities with different trait variations due to their different local characteristics.

5. The composition of the bird community varies with the increasing level of urbanization, with increasing GS size, and between the two studied GS types. 


\section{Materials and methods}

\section{Study area}

We carried out this study in Göttingen, a city with an area of $117 \mathrm{~km}^{2}$ and a population of 120,000 residents. This city is situated at $150 \mathrm{~m}$ a.s.1. in Lower Saxony, Germany (51 $32^{\prime}$ 28.61'” 9 $54^{\prime} 56.89^{\prime \prime E}$ ) (Szücs and Jaszczak 2013). The region around the city mainly consists of mosaics of intensive arable land, grassland and forest. The climate is temperate with an average annual temperature of $8.5^{\circ} \mathrm{C}$ and $650 \mathrm{~mm}$ average annual rainfall. Göttingen is considered as the second greenest city in Germany, because of its large-scale forests (more than $3700 \mathrm{ha}$ ), parks (120 ha) and allotments (68 ha). In Germany, there are over one million allotments, and Göttingen has 20 allotment societies, and a total of 29 allotment complexes (hereafter allotments). They are typically situated in smaller complexes next to each other, and individual allotments have a size of few hundred square meters, on which a bungalow, a few fruit trees and bushes, a small lawn and a flower and/or vegetable garden can be found. (Figure S1). There are numerous parks of various sizes in Göttingen (from 0.1 to $24 \mathrm{ha}$ ), which show different characteristics to allotments. These habitats include green strips, flower or lawn areas, shrubs and a high density of deciduous and coniferous trees, including new plantings along with older and taller individual trees.

\section{Study design}

We performed field surveys in allotments and parks. To determine the level of urbanization around all GSs, we calculated percentage cover of impervious surfaces in a $500 \mathrm{~m}$ radius buffer around each potential GS (29 allotments, 45 parks) using the European Urban Atlas map of Göttingen issued by European Environment Agency in 2012 and QGIS software, version 3.4.1 (QGIS Development Team 2018). This radius has been found to be an appropriate spatial scale for analyzing the responses of bird communities to urbanized landscapes (Pennington et al. 2008; Lee et al. 2019). First, we selected all artificial landscape elements, which were related to urbanization based on the mapping guide of European Urban Atlas: urban fabrics; industrial, commercial, public, military, private and transport units; mines, dumps and construction sites (European Commission 2016). Then, we determined the degree of soil sealing for these elements considering the interval values specified in the guide. In cases of landscape elements, where these values were not specified, we made estimations by comparison of their polygons with Google aerial photographs captured in 2019 (for the selected landscape elements and their average degree of soil sealing see Table S1). Finally, we pooled and weighted the percentage cover of each landscape element by their average degree of soil sealing within a
$500 \mathrm{~m}$ radius buffer around each GS. This resulted in an urbanization gradient defined according to the proportion of impervious surfaces among the sites that ranged between $1.8-75.9 \%$.

We measured the size of each GS and shrub and tree canopy cover around each sampling point as local variables. We excluded the smallest ( $<0.9$ ha) and the largest ( $>9.0$ ha) GSs and from the remaining potential GSs, we selected 17 allotments and 17 parks for field observations along independent urbanization gradients (Fig. 1; Table 1; Appendix S1). Shrub and tree canopy cover percentage was estimated in a $50 \mathrm{~m}$ radius buffer around each bird observation point based on in-field observations and additional aerial photographs. Parks are characterized by higher tree cover percentage and both GS types have a similar shrub cover within their area, and a similar size and impervious surface percentage in the surrounding matrix (Table 1 ).

\section{Bird surveys and functional traits}

We used a $50 \mathrm{~m}$ fixed radius point count method for bird observations (Bibby et al. 2000). Within each GS, we designated one or, if possible, two non-overlapping bird observation points. We selected 28 observation points within allotments and 24 points within parks and used these as replicates in all analyses, meaning that several allotments and parks contained two non-overlapping observation points. Two censuses were performed in 2017, the first between 5-9th May and the second between 16-21st May (the month of peak breeding activity and hence that with the highest detectability). All bird surveys were conducted by PB on clear, windless days between 6:00 and 10:00 (DeGraaf et al. 1991). Point counts were done by entering the survey point, waiting for one minute and recording for five minutes all birds singing or being present within a radius of $50 \mathrm{~m}$ (Gayer et al. 2019). From all recorded bird species (60), we excluded species for which it was not clear that they were definitely using a given site, namely raptors, aerial hunters (swifts and swallows) and

Table 1 Mean (SEM) of areas, impervious surface percentage in the surrounding matrix, shrub and tree covers of allotments and parks and their comparison based on general and generalized linear models. $* P<0.05$

\begin{tabular}{|c|c|c|c|c|}
\hline & Allotment & Park & Estimate & $\pm 95 \% \mathrm{CI}$ \\
\hline Size $(\mathrm{ha})^{\mathrm{a}}$ & $3.8(0.3)$ & $3.9(0.5)$ & 0.044 & \pm 1.133 \\
\hline Impervious surfaces $(\%)^{\mathrm{b}}$ & $38.8(3.4)$ & $43.7(4.4)$ & 0.202 & \pm 1.108 \\
\hline $\operatorname{Shrub}(\%)^{\mathrm{b}}$ & $16.5(1.4)$ & $16.7(2.5)$ & 0.018 & \pm 1.466 \\
\hline Tree $(\%)^{\mathrm{b}}$ & $6.6(1.3)$ & $37.2(4.6)$ & 2.119 & $\pm 1.702 *$ \\
\hline
\end{tabular}

${ }^{a}$ Models were fitted with normal distribution

${ }^{\mathrm{b}}$ Models were fitted with binomial distribution 


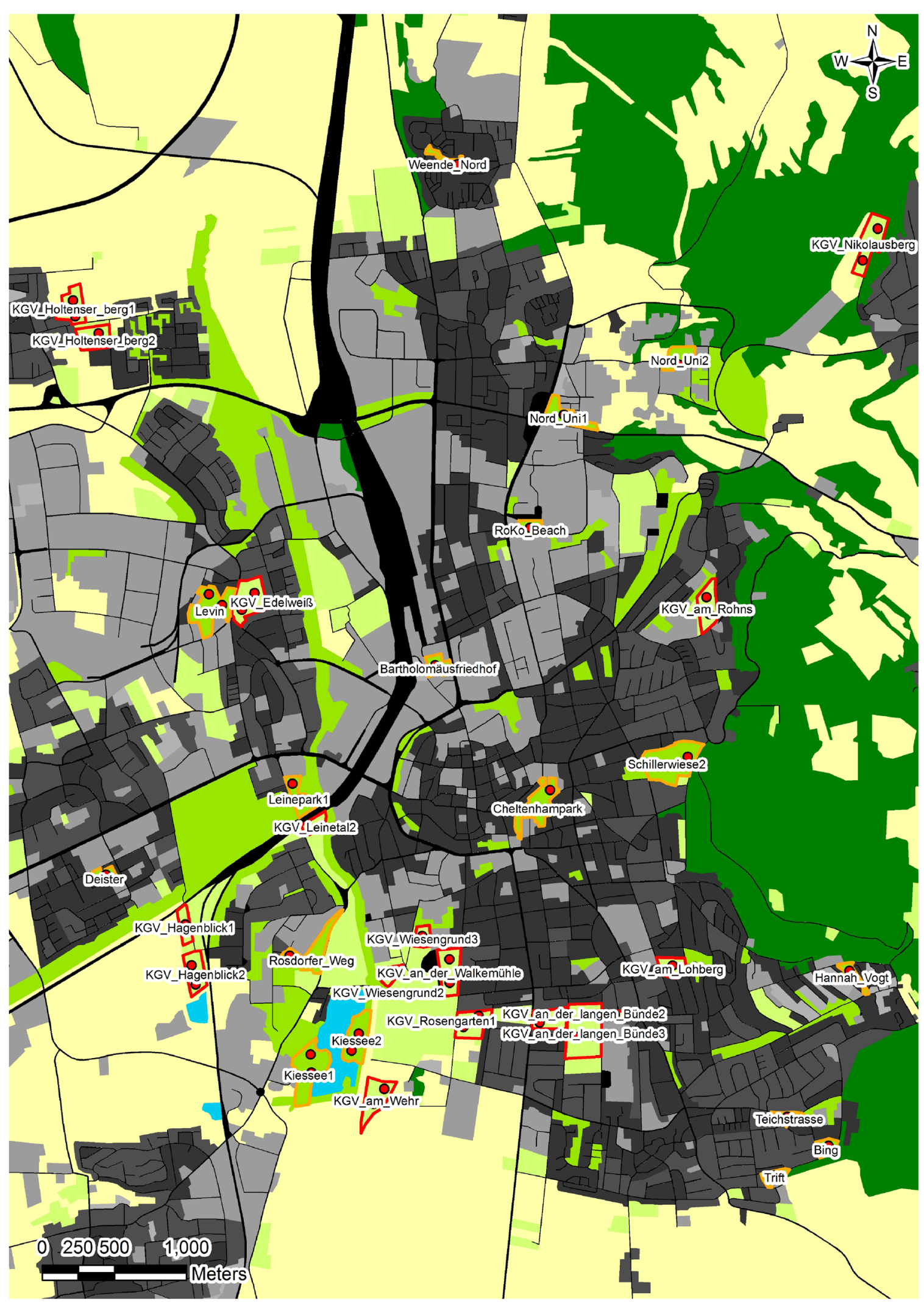

Fig. 1 Location of 52 observation points within the city of Göttingen, Germany. Allotments are marked with red borders and parks are marked with orange borders. The polygons marked with different colours are as follows: dark green: forest; green; green urban areas; light green: sports and leisure facilities; pale yellow: arable lands; light grey to dark grey: urban fabrics with increasing sealed area (SL) percentage: S.L.: $<10 \%$, S.L.: $10-30 \%$, S.L.: $30 \%-50 \%$, S.L.: $50-80 \%$, S.L.: $>80 \%$; black: roads, railways and associated lands 
aquatic species, as well as individuals flying over, from the analyses.

We took five avian functional traits into consideration: body mass, foraging technique, diet, nest location and migration status. Average body mass for each species was taken from Cramp and Perrins (1994) and was expressed in grams as a continuous variable. We used foraging technique (ground prober, ground gleaner, understory gleaner, bark forager and canopy foliage gleaner or hawker, representing elevation gradient) and diet (granivore, mixed diet and insectivore, representing an ordinal carnivory gradient) as feeding traits (Cramp and Perrins 1994; Barbaro and van Halder 2009). Finally, we classified bird species according to their nest location (open on ground, open in shrub, open in tree and cavity, representing an elevation gradient) (Cramp and Perrins 1994; Barbaro and van Halder 2009) and their migration status (resident, temperate/partial migrant and tropical migrant species, representing a migration distance gradient) (Sudfeldt et al. 2012; Bairlein et al. 2014). For correlations between selected traits, see Table S2.

\section{Statistical analysis}

We pooled data across sampling dates, and used the R 3.5.1 statistical environment (R Core Team 2018) for all analyses. Before the analyses, we log-transformed GS size (measured in square meters) in order to meet condition of linearity, and constrained the values of log-transformed GS size and impervious surface percentage between 0 and 1 to bring these variables on the same scale. We used general and generalized linear models (GLMs with normal and binomial distribution) and calculated Pearson correlation coefficients to check whether our explanatory variables were independent from each other. We found no difference in the percentage of impervious surfaces around the two GS types (allotment and park) and in the size of the two GS types (Table 1), and also no correlation between impervious surface percentage and GS size (Pearson $r=-0.12, P=0.372$ ). We also constrained all trait values to between 0 and 1 to account for the different number of categories. We calculated community weighted means (CWM) for each trait, using the averages of trait values weighted by the relative abundances of each bird species at each observation point $(N=52)$ (Ricotta and Moretti 2011). We used the 'FD' package version 1.0-12 to calculate CWM indices (Laliberte and Legendre 2010).

We used general linear mixed-effects models (GLMMs) with normal errors to test whether urbanization, GS type, and size (explanatory variables) had a significant effect on species richness and CWM of each trait (response variables). The full model included impervious surface percentage, GS type, and size, as well as their two-way interactions as fixed factors, and location of GS as random factor to consider spatial non-independence of bird observation points within the same GS. There was no evidence of residual spatial autocorrelation in any models (fitted using the "ncf" package version 1.2-8; Bjørnstad 2019) (Fig. S2). We also built GLMMs with normal errors to see if local variables (shrub and tree percentage) could effectively explain the effects of GS types on the same response variables (Table S3). We used the 'nlme' package version 3.1-137 to build GLMMs (Pinheiro et al. 2018). We calculated all models nested in the global model by the command 'dredge' in the package 'MuMIn' version 1.42.1 (Barton 2018) and compared them based on Akaike Information Criterion corrected for small sample size (AICc). We performed model averaging if the top model and subsequent models differed by less than six units in AICc (Bolker et al. 2009).

We performed redundancy analysis (RDA) to assess the variability in species composition of bird communities explained by the predictor variables impervious surface percentage, GS type, and size. We transformed the community data matrices using the Hellinger-transformation before the analysis (Legendre and Gallagher 2001) and we used permutation tests, calculating 999 permutations to assess the statistical significance of predictor variables using the package 'vegan' version 2.5-3 (Oksanen et al. 2018). We also performed indicator species analysis (Dufrêne and Legendre 1997) to identify potential indicator species for each GS type by using the 'indval' function of the 'labdsv' package version 1.8-0 (Roberts 2016).

\section{Results}

In the 52 observation points, we observed 1449 birds belonging to 47 species (Table S4). The most abundant species were common blackbird (Turdus merula), great tit (Parus major) and house sparrow (Passer domesticus) representing $37.5 \%$ of all observed birds. We recorded 37 species and 733 individuals in allotments, and 44 species and 716 individuals in parks.

Overall, impervious surface percentage in the surrounding matrix had no effect on species richness nor on the functional traits of birds (Table 2). In contrast, GS type had a significant effect on species richness as we found more species in parks compared to allotments. We found more tropical migrants and a significantly higher number of individuals with lower nesting location (ground or shrub level) in parks, and more cavity nesters in allotments (Table 2; Fig. 2). Body mass was significantly influenced by GS size in interaction with GS type, as the proportion of birds with larger body mass increased with the increasing park size (Table 2; Fig. 3). There was no evidence of an interaction between explanatory variables in other analyses. 
Table 2 Summary table for GLMM results after multimodel averaging of the best candidate models, showing the relative importance of each explanatory variable on species richness and community weighted mean (CWM) indices of birds. The following traits were considered: body size (continuous variable in gram), foraging technique (ground prober, ground gleaner, understory gleaner, bark forager, canopy foliage gleaner/hawker), diet (granivore, mixed diet, insectivore), nest location (open on ground, open in shrub, open in tree, cavity), migration status (resident, temperate/partial migrant, tropical migrant)

\begin{tabular}{|c|c|c|c|c|}
\hline Model $^{\mathrm{a}}$ & Variable $^{\mathrm{b}}$ & Relative importance $(\%)^{\mathrm{c}}$ & Multimodel estimate & $\pm 95 \% \mathrm{CI}^{\mathrm{d}}$ \\
\hline Species richness & $\mathrm{GS}(\mathrm{P} / \mathrm{A})$ & 97 & 2.030 & $\pm 0.039^{*}$ \\
\hline \multirow[t]{5}{*}{$(0.23 / 0.43 ; 9)$} & Impervious surface & 46 & -1.695 & \pm 0.380 \\
\hline & GS size & 31 & -0.173 & \pm 0.931 \\
\hline & GS $\times$ Impervious surface & 12 & 1.789 & \pm 0.530 \\
\hline & $\mathrm{GS} \times \mathrm{GS}$ size & 7 & -1.253 & \pm 0.669 \\
\hline & Impervious surface $\times$ GS size & 5 & -3.124 & \pm 0.635 \\
\hline CWM Body mass & $\mathrm{GS}(\mathrm{P} / \mathrm{A})$ & 94 & 0.013 & \pm 0.732 \\
\hline \multirow[t]{5}{*}{$(0.29 / 0.46 ; 10)$} & GS size & 68 & -0.039 & \pm 0.584 \\
\hline & $\mathrm{GS} \times \mathrm{GS}$ size & 55 & 0.143 & $\pm 0.025^{*}$ \\
\hline & Impervious surface & 33 & -0.026 & \pm 0.619 \\
\hline & Impervious surface $\times$ GS size & 7 & 0.189 & \pm 0.283 \\
\hline & $\mathrm{GS} \times$ Impervious surface & 7 & 0.028 & \pm 0.692 \\
\hline CWM Foraging & GS size & 30 & -0.010 & \pm 0.172 \\
\hline \multirow[t]{3}{*}{$(0.08 / 0.63 ; 8)$} & Impervious surface & 29 & -0.006 & \pm 0.131 \\
\hline & $\mathrm{GS}(\mathrm{P} / \mathrm{A})$ & 26 & 0.000 & \pm 0.059 \\
\hline & Impervious surface $\times$ GS size & 4 & -0.286 & \pm 0.474 \\
\hline CWM Diet & $\mathrm{GS}(\mathrm{P} / \mathrm{A})$ & 40 & 0.033 & \pm 0.341 \\
\hline \multirow[t]{5}{*}{$(0.07 / 0.41 ; 11)$} & GS size & 35 & -0.040 & \pm 0.603 \\
\hline & Impervious surface & 28 & 0.022 & \pm 0.746 \\
\hline & $\mathrm{GS} \times \mathrm{GS}$ size & 3 & -0.017 & \pm 0.878 \\
\hline & $\mathrm{GS} \times$ Impervious surface & 3 & 0.040 & \pm 0.743 \\
\hline & Impervious surface $\times$ GS size & 3 & -0.223 & \pm 0.430 \\
\hline CWM Nesting & $\mathrm{GS}(\mathrm{P} / \mathrm{A})$ & 94 & -0.091 & $\pm 0.016^{*}$ \\
\hline \multirow[t]{5}{*}{$(0.23 / 0.64 ; 11)$} & GS size & 48 & -0.056 & \pm 0.513 \\
\hline & Impervious surface & 32 & -0.010 & \pm 0.890 \\
\hline & $\mathrm{GS} \times \mathrm{GS}$ size & 10 & 0.038 & \pm 0.734 \\
\hline & $\mathrm{GS} \times$ Impervious surface & 6 & 0.000 & \pm 0.997 \\
\hline & Impervious surface $\times$ GS size & 5 & -0.260 & \pm 0.353 \\
\hline CWM Migration & $\mathrm{GS}(\mathrm{P} / \mathrm{A})$ & 94 & 0.067 & $\pm 0.020 *$ \\
\hline \multirow[t]{5}{*}{$(0.23 / 0.44 ; 10)$} & GS size & 67 & 0.075 & \pm 0.188 \\
\hline & Impervious surface & 29 & 0.001 & \pm 0.982 \\
\hline & $\mathrm{GS} \times \mathrm{GS}$ size & 14 & -0.005 & \pm 0.952 \\
\hline & $\mathrm{GS} \times$ Impervious surface & 6 & -0.021 & \pm 0.833 \\
\hline & Impervious surface $\times$ GS size & 4 & 0.048 & \pm 0.836 \\
\hline
\end{tabular}

${ }^{\mathrm{a}}$ Models were fitted with normal distribution (marginal/conditional $\mathrm{R}^{2}$ of full model; number of candidate models, $\Delta \mathrm{AIC}<6$ )

${ }^{\mathrm{b}}$ GS effect: P (park) vs. A (allotment) - positive value means higher number in parks vs. allotments; impervious surface effect: percentage, ranged between 0 and 1; GS size effect: square meters, log-transformed and ranged between 0 and 1

${ }^{\mathrm{c}}$ Each variable's importance within the best candidate models $(\triangle \mathrm{AIC}<6)$

d Significance levels: $*:<0.05,(*): \geq 0.05$ and $<0.1$

Among local variables, increasing proportion of tree cover had a significant positive effect on species richness and on the presence large-bodied birds. Increasing shrub cover percentage resulted in a significantly higher proportion of canopy foliage gleaners/hawkers, insectivores and ground nesters in the bird community (Table S3).

GS type and size explained a significant part of the variation in community composition $(F=6.661, P=0.001 ; F=$ 
$1.684, P=0.035$, respectively) according to the redundancy analysis of bird communities (Fig. 4), whereas impervious surface percentage had no effect $(F=0.909, P=0.551)$. The indicator species analysis identified six species as indicators of allotments and seven species as indicators of parks. Linnet (Carduelis cannabina), great tit (Parus major), Eurasian tree sparrow (Passer montanus), black redstart (Phoenicurus ochruros), common redstart ( $P$. phoenicurus) and European serin (Serinus serinus) showed preference for allotments, whereas European goldfinch (Carduelis carduelis), European robin (Erithacus rubecula), blackcap (Sylvia atricapilla), chaffinch (Fringilla coelebs), wood pigeon (Columba palumbus), chiffchaff (Phylloscopus collybita) and fieldfare (Turdus pilaris) were associated with parks (Table S4; Fig. 4).

\section{Discussion}

We studied the effects of the surrounding urban matrix of GSs, GS type (allotment vs. park), and size on species richness, functional traits and community composition of birds. Contrary to our expectations (1,2 and, 3 ), our results showed that increasing level of urbanization and increasing GS size had no effect on bird species richness nor on the examined functional traits. In accord with expectation (4), we found more ground or near-ground nesting and more migrant birds

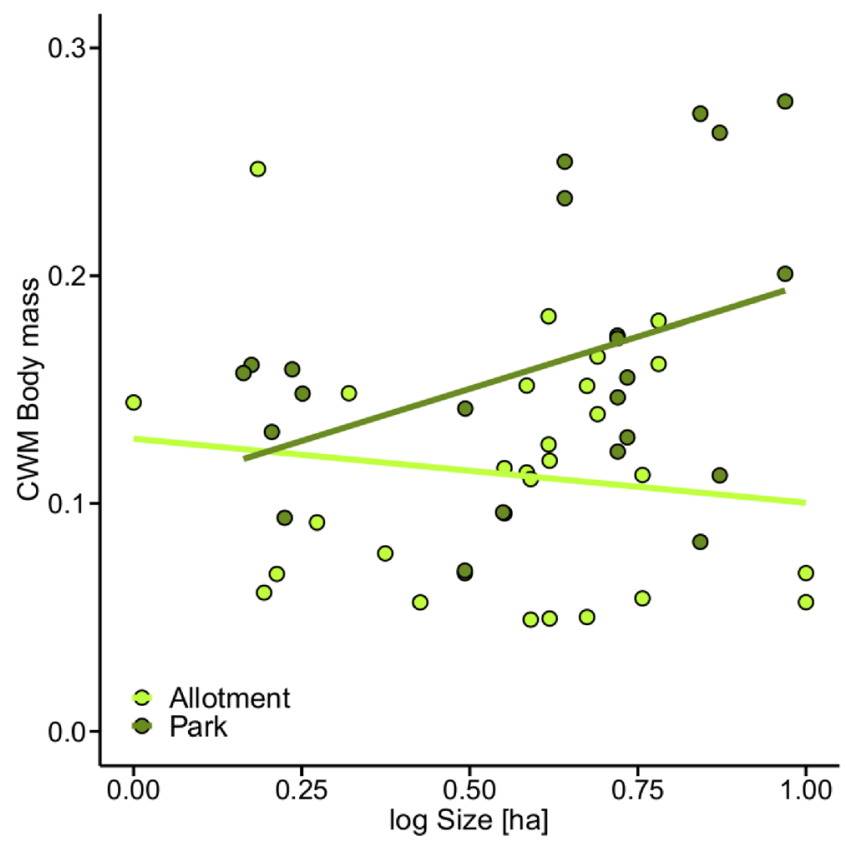

Fig. 3 Effect of GS size (log transformed and ranged between 0 and 1) on community weighted mean (CWM) body mass values of birds in allotments (light green dots and line) and parks (dark green dots and line)

in parks, but we found no differences regarding other trait values (foraging technique and diet of birds) between the two GI types, showing that allotments, despite their lower species richness, act as important bird habitats. Concerning expectation (5), community composition differed between (a)

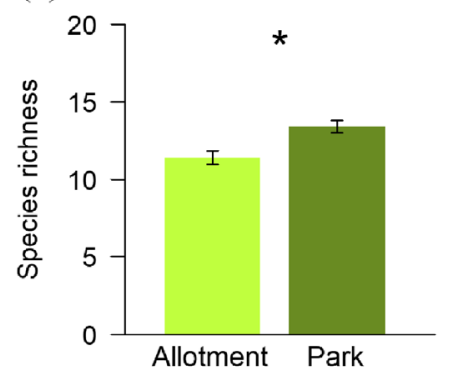

(d)

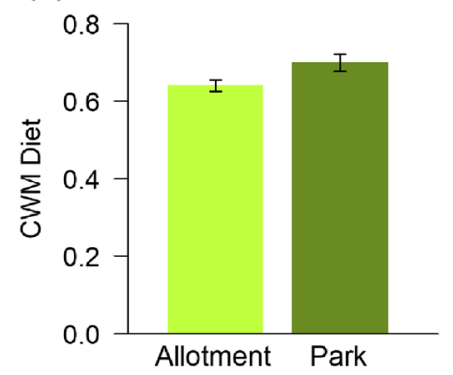

(b)

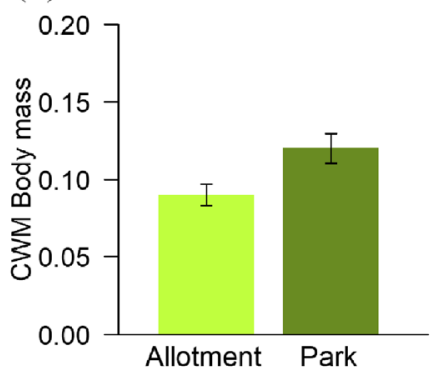

(e)

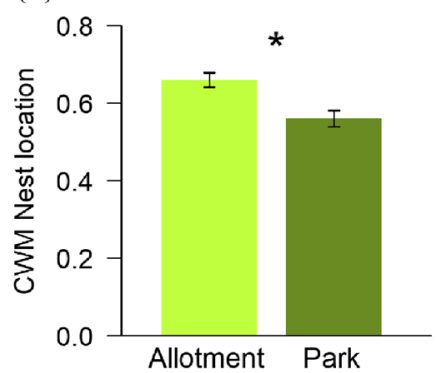

(c)

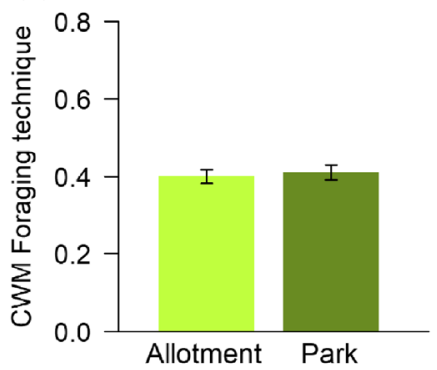

(f)

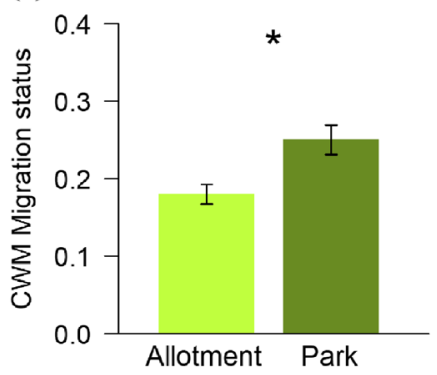

Fig. 2 Species richness and community weighted mean (CWM) indices of bird communities. (a) Species richness; (b) CWM Body mass (continuous in gram); (c) CWM Foraging technique (ground prober, ground gleaner, understory gleaner, bark forager, canopy foliage gleaner/hawker); (d) CWM Diet (granivore, mixed diet, insectivore); (e) CWM Nest location (open on ground, open in shrub, open in tree, cavity); (f) CWM Migration status (resident, temperate/partial migrant, tropical migrant). Significant differences between allotment and park are indicated by a star $(P<0.05)$ 


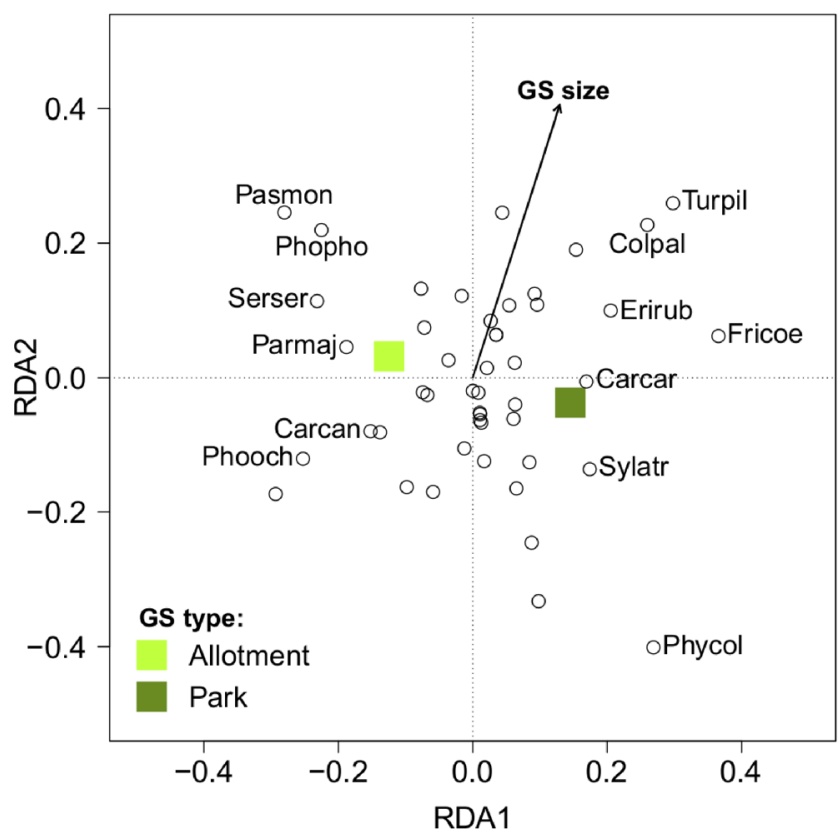

Fig. 4 Redundancy analysis biplot for all species (open dots) showing the significant effect of GS type (light green square: allotment, dark green square: park) and GS size (arrow) on bird community. Separation of species along the first RDA axis (i.e. to the left of allotment symbol or to the right of park symbol) show preference for one of the GS types. The direction of the arrow points to an increase of GS size. For visibility, only indicator species of each GS type (with significant indicator values) are shown. Species codes consist of the first three letters of genus plus the first three letters of species names (for species names and indicator values see Table S4)

allotments and parks and with increasing GS size, but was not determined by an increasing level of urbanization in the surrounding matrix.

\section{Effects on species richness}

We did not find any relationship between species richness and increasing levels of urbanization. Moreover, we recorded 47 bird species in the city which can be considered quite diverse in an urban context. Previous landscape studies in the surroundings of Göttingen showed a lower avian species richness in different rural areas such as agricultural fields (35 species), hedgerows (including beech forests) (32 species) and grasslands (46 species) (Batáry et al. 2010; Batáry et al. 2012; Ernst et al. 2017) (without considering raptors, aerial hunters and aquatic species). This is an unexpected result, because the number of bird species generally decreases towards the city center (as reviewed by Chase and Walsh 2006 and Batáry et al. 2018). The lack of decreasing avian species richness with an increasing level of urbanization may primarily be due to the characteristics of the study area. Göttingen is considered as a city with a large expanse of green areas (GT 2018), which provide not only a larger proportion of green surface, but also greater connectivity between green habitat patches in the city. As a result, these green fragments embedded in an urban matrix can serve as movement corridors and stepping stones for different bird species (Fernández-Juricic and Jokimäki 2001; CarbóRamírez and Zuria 2011; Callaghan et al. 2019).

We found that increasing size of GS had no effect on avian species richness despite the fact that large green areas in urban environments can harbor more species compared to small ones (Fernández-Juricic and Jokimäki 2001; Carbó-Ramírez and Zuria 2011; Callaghan et al. 2018). This suggests that habitat quality of these areas are more decisive than either size or isolation for the richness of bird communities (Nielsen et al. 2014). In our study, parks had the appropriate characteristics for conserving species rich bird communities. Parks are considered as important biodiversity hotspots in cities, especially if they are not intensively managed, or even unmanaged, and provide habitat diversity and microhabitat heterogeneity (Fernández-Juricic and Jokimäki 2001; Shwartz et al. 2008; Nielsen et al. 2014). The positive effect of parks can be confirmed by their high tree coverage, which was also a significant predictor of bird species richness. Trees are considered as key vegetation components for urban dwelling birds for roosting, nesting, hiding and foraging (MacGregor-Fors and Schondube 2011). Thus the denser, older, and higher tree canopy cover provided by parks supports sensitive forest species, and hence plays an important role in enhancing species richness in urban areas (Palomino and Carrascal 2006; Taylor et al. 2016; Callaghan et al. 2018).

We showed that the role of allotments in reducing species loss caused by urbanization is also important, and is probably enhanced by the presence of parks within cities. This can be confirmed by the fact that we observed different indicator species associated with parks and allotments, despite similar shrub cover in both GS types (Table 1). This vegetation component is also positively related to bird species richness in the urban environment by providing additional feeding resources (insects, seeds and fruits), shelter from predators, extreme weather and human disturbance, and important nesting sites (Ortega-Álvarez and MacGregor-Fors 2009; MacGregor-Fors and Schondube 2011; Paker et al. 2014).

\section{Effects on functional traits and community composition}

We found differences in species composition between parks and allotments and with increasing GS size. This also resulted in differences in case of certain traits, such as nest location, body mass and migration status.

Although the shrub cover was similar in the examined GS types, and this vegetation component positively affected the presence of low-nesting birds, we found more ground or nearground nesting birds in parks compared to allotments. It is an interesting result, because high nesters are generally 
associated with tree availability (Croci et al. 2008). At the same time, the majority of indicator species were tree-nesters in parks and cavity-nesters in allotments, suggesting the effect of larger number of installed nest boxes observed in allotments (PB personal observation). For example, the abundant great tit and tree sparrow often occupy artificial nests. Von Post and Smith (2015) showed that addition of artificial nests had a positive effect on tree sparrows, which can compensate for competition for nest sites with the more aggressive house sparrows (Passer domesticus). Taking into account other cavity-nesting species, like black redstart and common redstart, both species were associated with allotments despite that black redstart shows a strong preference for urban areas with little tree cover, whereas the congeneric species, common redstart, prefers park-like, wooded habitats (Sedláček et al. 2004). This suggests that they were able to utilize different resources within allotments, which may contribute to the reduction of interspecific territoriality. To confirm this, further investigations, including on cavity resources in these habitats, are needed.

We found more birds with larger body mass with increasing park size despite the fact that urban public open places with low densities of trees are generally preferred by largebodied species (Ikin et al. 2012), suggesting that they should be more abundant in allotments. It is important to note that birds with the largest body mass among indicator species, such as common wood pigeon and fieldfare, showed a preference for parks and these species also preferred large GIs. Parks can offer mature tree stands containing diverse tree species with tall individuals, which have a significant positive effect on the breeding success of fieldfares (Czechowski et al. 2017). Additionally, it also provides appropriate living conditions for wood pigeons, which generally have an arboreal character and great flexibility to change their habitat use in urban environments (Fey et al. 2015). Based on our results, not only the presence of wooded habitats, but also their size is important and hence large parks provide more suitable habitats for these species in an urban environment.

Our results suggest that parks are also more suitable habitats than allotments for species that have migratory propensities. In general, tropical migrants occurring in urban environments are insectivores, foraging on the foliage of trees or shrubs and abundant in wooded habitats. Urbanization often results in the decline of this kind of habitat contributing to the reduction of the available resources for these species (MacGregor-Fors et al. 2010). Interestingly, tree cover had no effect on the migration trait of birds, which suggests that other local factors may influence the presence of migratory species in the studied green habitats. We think that allotments provide more resources for non-migrant species, such as for great tit and tree sparrow. The presence of sedentary birds in these habitats can contribute to the low density of migratory birds due to their faster shift in phenology to earlier dates and the better ability to defend the occupied nesting and foraging sites throughout the year (Kark et al. 2007).

Both GI types harbored bird communities with similar foraging technique and diet traits regardless of their size. However, shrub cover had positive impacts on these traits in these habitats, highlighting the important contribution of this vegetation component to the presence of canopy forager and insectivorous species (Ikin et al. 2012).

Contrary to previous findings (e.g. Kark et al. 2007; Croci et al. 2008; Chamberlain et al. 2017; Mayorga et al. 2020), we found no evidence that community composition or functional traits of birds such as foraging technique, diet, nest location, migration status or even body mass, changed with increasing level of urbanization. This outcome indicates that a sufficient amount of allotments and parks in cities might moderate the changes in bird communities and contribute to mitigating the environmental filter effect of urbanization by providing functional heterogeneity in bird communities. Although increasing levels of urbanization tends to filter traits contributing to the presence of urban adapter species (Chace and Walsh 2006; Kark et al. 2007; Croci et al. 2008), areas with large-scale vegetation cover can support more urban avoider species by providing abundant and diverse insect communities for tree foraging insectivores (Máthé and Batáry 2015), more shelter for disturbance sensitive small-bodied species and ground nesters (Fernández-Juricic and Jokimäki 2001), and also adequate habitat conditions for migratory species (Kohut et al. 2009).

\section{Conclusion}

Our results highlighted that green areas embedded in an urban matrix play an important role in providing favourable environmental conditions for numerous bird species. In our study, avian species richness and community composition of GSs was not affected by the increasing level of urbanization in the surrounding matrix and they were better explained by the type as well as the size of the GSs. In addition, species richness and some bird traits were also influenced by the vegetation structure (shrub and tree cover) of GSs. Although parks were marginally more important for the avifauna than allotments in terms of species richness, we found that both habitats supported a relatively high number of species. As parks and allotments supported partly different species and trait variations (more tree and ground nesters and tropical migrants in parks, and more cavity nesters and resident birds in allotments), their beneficial effect on birds in cities is complementary.

In conclusion, our results suggest that in addition to providing an adequate amount of green space, management measures should also focus on maintaining their diverse local characteristics in order to maintain diverse and functionally 
rich bird communities. Although allotments are primarily designed for the benefit of humans, their role in enhancing species richness can be increased when they are interconnected with other green spaces as an integral part of an urban green infrastructure.

Supplementary Information The online version contains supplementary material available at https://doi.org/10.1007/s11252-020-01083-2.

Acknowledgements This study was supported by the Economic Development and Innovation Operational Programme of Hungary (GINOP-2.3.2-15-2016-00019) and by the Hungarian National Research, Development and Innovation Office (NKFIH KKP 133839).

Authors' contributions P.B. conceived the study; P.B. and B.D. selected the study sites; P.B. performed the bird surveys; D.K. analyzed data with substantial input from R.G. and P.B.; D.K. wrote the paper with substantial input from all authors.

Funding Open Access funding provided by ELKH Centre for Ecological Research.

Data availability Bird data is stored in the https://zenodo.org/record/ 4314419 repository database.

Open Access This article is licensed under a Creative Commons Attribution 4.0 International License, which permits use, sharing, adaptation, distribution and reproduction in any medium or format, as long as you give appropriate credit to the original author(s) and the source, provide a link to the Creative Commons licence, and indicate if changes were made. The images or other third party material in this article are included in the article's Creative Commons licence, unless indicated otherwise in a credit line to the material. If material is not included in the article's Creative Commons licence and your intended use is not permitted by statutory regulation or exceeds the permitted use, you will need to obtain permission directly from the copyright holder. To view a copy of this licence, visit http://creativecommons.org/licenses/by/4.0/.

\section{References}

Bairlein F, Dierschke J, Dierschke V, Salewski V, Geiter O, Hüppop K, Köppen U, Fiedler W (2014) Atlas des Vogelzuges. Ringfunde deutscher Brut-und Gastvögel (Atlas of bird migration: Ringing recoveries of German breeding and migrating birds). Aula-Verlag, Wiebelsheim

Baldock KCR, Goddard MA, Hicks DM, Kunin WE, Mitschunas N, Morse H, Osgathorpe LM, Potts SG, Robertson KM, Scott AV, Staniczenko PA, Stone GN, Vaughan IP, Memmott J (2019) A systems approach reveals urban pollinator hotspots and conservation opportunities. Nat Ecol Evol 3:363-373. https://doi.org/10.1038/ s41559-018-0769-y

Barbaro L, van Halder I (2009) Linking bird, carabid beetle and butterfly life-history traits to habitat fragmentation in mosaic landscapes. Ecography 32:321-333. https://doi.org/10.1111/j.1600-0587.2008. 05546.x

Barth BJ, FitzGibbon SI, Wilson RS (2015) New urban developments that retain more remnant trees have greater bird diversity. Landsc Urban Plan 136:122-129. https://doi.org/10.1016/j.landurbplan. 2014.11.003
Barton K (2018) MuMIn: R functions for model selection and model averaging. $\mathrm{R}$ package version $1(42): 1$

Batáry P, Matthiesen T, Tscharntke T (2010) Landscape-moderated importance of hedges in conserving farmland bird diversity of organic vs. conventional croplands and grasslands. Biol Conserv 143:2020 2027. https://doi.org/10.1016/j.biocon.2010.05.005

Batáry P, Kovács-Hostyánszki A, Fischer C, Tscharntke T, Holzschuh A (2012) Contrasting effect of isolation of hedges from forests on farmland vs. woodland birds. Community Ecol 13:155-161. https://doi.org/10.1556/ComEc.13.2012.2.4

Batáry P, Kurucz K, Suarez-Rubio M, Chamberlain DE (2018) Nonlinearities in bird responses across urbanization gradients: a metaanalysis. Glob Chang Biol 24:1046-1054. https://doi.org/10.1111/ gcb.13964

Bibby CJ, Burgess ND, Hill DA, Mustoe S (2000) Bird census techniques. Academic Press, London

Bjørnstad ON (2019) ncf: Spatial Covariance Functions. R package version 1:2-8

Bolker BM, Brooks ME, Clark CJ, Geange SW, Poulsen JR, Stevens MHH, White JSS (2009) Generalized linear mixed models: a practical guide for ecology and evolution. Trends Ecol Evol 24:127135. https://doi.org/10.1016/j.tree.2008.10.008

Borysiak J, Mizgajski A, Speak A (2017) Floral biodiversity of allotment gardens and its contribution to urban green infrastructure. Urban Ecosyst 20:323-335. https://doi.org/10.1007/s11252-016-0595-4

Callaghan CT, Major RE, Lyons MB, Martin JM, Kingsford RT (2018) The effects of local and landscape habitat attributes on bird diversity in urban greenspaces. Ecosphere 9:e02347. https://doi.org/10.1002/ ecs 2.2347

Callaghan CT, Bino G, Major RE, Martin JM, Lyons MB, Kingsford RT (2019) Heterogeneous urban green areas are bird diversity hotspots: insights using continental-scale citizen science data. Landsc Ecol 34: 1231-1246. https://doi.org/10.1007/s10980-019-00851-6

Carbó-Ramírez P, Zuria I (2011) The value of small urban greenspaces for birds in a Mexican city. Landsc Urban Plan 100:213-222. https://doi.org/10.1016/j.landurbplan.2010.12.008

Chace JF, Walsh JJ (2006) Urban effects on native avifauna: a review. Landsc Urban Plan 74:46-69. https://doi.org/10.1016/j.landurbplan. 2004.08.007

Chamberlain DE, Gough S, Vaughan H, Vickery JA, Appleton GF (2007a) Determinants of bird species richness in public green spaces. Bird Study 54:87-97. https://doi.org/10.1080/ 00063650709461460

Chamberlain DE, Toms MP, Cleary-McHarg R, Banks AN (2007b) House sparrow (Passer domesticus) habitat use in urbanized landscapes. J Ornithol 148:453-462. https://doi.org/10.1007/s10336007-0165-x

Chamberlain DE, Kibuule M, Skeen R, Pomeroy D (2017) Trends in bird species richness, abundance and biomass along a tropical urbanization gradient. Urban Ecosyst 20:629-638. https://doi.org/10.1007/ s11252-016-0621-6

Chong KY, Teo S, Kurukulasuriya B, Chung YF, Rajathurai S, Tan HTW (2014) Not all green is as good: different effects of the natural and cultivated components of urban vegetation on bird and butterfly diversity. Biol Conserv 171:299-309. https://doi.org/10.1016/j. biocon.2014.01.037

Clergeau P, Jokimäki J, Savard JPL (2001) Are urban bird communities influenced by the bird diversity of adjacent landscapes? J Appl Ecol 38:1122-1134. https://doi.org/10.1046/j.1365-2664.2001.00666.x

Clergeau P, Croci S, Jokimäki J, Kaisanlahti-Jokimäki ML, Dinetti M (2006) Avifauna homogenisation by urbanisation: analysis at different European latitudes. Biol Conserv 127:336-344. https://doi.org/ 10.1016/j.biocon.2005.06.035

Conole LE, Kirkpatrick JB (2011) Functional and spatial differentiation of urban bird assemblages at the landscape scale. Landsc Urban Plan 100:11-23. https://doi.org/10.1016/j.landurbplan.2010.11.007 
Cramp S, Perrins CM (1994) The birds of the western Palearctic, vol IVIX. Oxford University Press, Oxford

Croci S, Butet A, Clergeau P (2008) Does urbanization filter birds on the basis of their biological traits? Condor 110:223-240. https://doi.org/ 10.1525/cond.2008.8409

Czech B, Krausman PR, Devers PK (2000) Economic associations among causes of species endangerment in the United States. BioScience 50:593-601. https://doi.org/10.1641/0006-3568(2000) 050[0593:EAACOS]2.0.CO;2

Czechowski R, Tańska N, Mitrus C, Leniowski K, Węgrzyn E (2017) Breeding density and nest-site selection of urban population of the fieldfare Turdus pilaris in Rzeszow (SE Poland). Biologia 72:350356. https://doi.org/10.1515/biolog-2017-0035

DeGraaf RM, Geis AD, Healy PA (1991) Bird population and habitat surveys in urban areas. Landsc Urban Plan 21:181-188. https://doi. org/10.1016/0169-2046(91)90017-G

Dufrêne M, Legendre P (1997) Species assemblages and indicator species: the need for a flexible asymmetrical approach. Ecol Monogr 67:345-366. https://doi.org/10.1890/0012-9615(1997)067[0345: SAAIST]2.0.CO;2

Edmondson JL, Davies ZG, Gaston KJ, Leake JR (2014) Urban cultivation in allotments maintains soil qualities adversely affected by conventional agriculture. J Appl Ecol 51:880-889. https://doi.org/10. 1111/1365-2664.12254

Ernst LM, Tscharntke T, Batáry P (2017) Grassland management in agricultural vs. forested landscapes drives butterfly and bird diversity. Biol Conserv 216:51-59. https://doi.org/10.1016/j.biocon.2017.09. 027

European Commission (2016) Mapping guide for a European urban atlas. Version 4.7. https://land.copernicus.eu/user-corner/technicallibrary/urban-atlas-mapping-guide. Accessed 15 May 2019

Evans KL, Chamberlain DE, Hatchwell BJ, Gregory RD, Gaston KJ (2011) What makes an urban bird? Glob Chang Biol 17:32-44. https://doi.org/10.1111/j.1365-2486.2010.02247.x

Fernández-Juricic E, Jokimäki J (2001) A habitat island approach to conserving birds in urban landscapes: case studies from southern and northern Europe. Biodivers Conserv 10:2023-2043. https:// doi.org/10.1023/A:1013133308987

Fey K, Vuorisalo T, Lehikoinen A, Selonen V (2015) Urbanisation of the wood pigeon (Columba palumbus) in Finland. Landsc Urban Plan 134:188-194. https://doi.org/10.1016/j.landurbplan.2014.10.015

Filazzola A, Shrestha N, JS MI (2019) The contribution of constructed green infrastructure to urban biodiversity: a synthesis and meta-analysis. J Appl Ecol 56:2131-2143. https://doi.org/10.1111/13652664.13475

Garden J, McAlpine C, Peterson ANN, Jones D, Possingham H (2006) Review of the ecology of Australian urban fauna: a focus on spatially explicit processes. Austral Ecol 31:126-148. https://doi.org/ 10.1111/j.1442-9993.2006.01578.x

Gayer C, Kurucz K, Fischer C, Tscharntke T, Batáry P (2019) Agricultural intensification at local and landscape scales impairs farmland birds, but not skylarks (Alauda arvensis). Agric Ecosyst Environ 277:21-24. https://doi.org/10.1016/j.agee.2019.03.006

Geschke A, James S, Bennett AF, Nimmo DG (2018) Compact cities or sprawling suburbs? Optimising the distribution of people in cities to maximise species diversity. J Appl Ecol 55:2320-2331. https://doi. org/10.1111/1365-2664.13183

Grimm NB, Faeth SH, Golubiewski NE, Redman CL, Wu J, Bai X, Briggs JM (2008) Global change and the ecology of cities. Science 319:756-760. https://doi.org/10.1126/science.1150195

GT (2018) Göttingen ist zweitgrünste Stadt (Göttingen is the second greenest city). https://www.goettinger-tageblatt.de/Die-Region/ Goettingen/Goettingen-ist-Zweitgruenste-Stadt. Accessed 25 August 2019

Ikin K, Knight E, Lindenmayer DB, Fischer J, Manning AD (2012) Linking bird species traits to vegetation characteristics in a future urban development zone: implications for urban planning. Urban Ecosyst 15:961-977. https://doi.org/10.1007/s11252-012-0247-2

Kark S, Iwaniuk A, Schalimtzek A, Banker E (2007) Living in the city: can anyone become an 'urban exploiter'? J Biogeogr 34:638-651. https://doi.org/10.1111/j.1365-2699.2006.01638.x

Kohut SM, Hess GR, Moorman CE (2009) Avian use of suburban greenways as stopover habitat. Urban Ecosyst 12:487-502. https://doi. org/10.1007/s11252-009-0099-6

Laliberte E, Legendre P (2010) A distance-based framework for measuring functional diversity from multiple traits. Ecology 91:299-305. https://doi.org/10.1890/08-2244.1

Lee MB, Peabotuwage I, Gu H, Zhou W, Goodale E (2019) Factors affecting avian species richness and occupancy in a tropical city in southern China: Importance of human disturbance and open green space. Basic Appl Ecol 39:48-56. https://doi.org/10.1016/j.baae. 2019.08.003

Legendre P, Gallagher E (2001) Ecologically meaningful transformations for ordination of species data. Oecologia 129:271-280. https://doi. org/10.1007/s004420100716

MacGregor-Fors I, Schondube JE (2011) Gray vs. green urbanization: relative importance of urban features for urban bird communities. Basic Appl Ecol 12:372-381. https://doi.org/10.1016/j.baae.2011. 04.003

MacGregor-Fors I, Morales-Pérez L, Schondube JE (2010) Migrating to the city: responses of neotropical migrant bird communities to urbanization. Condor 112:711-717. https://doi.org/10.1525/cond. 2010.100062

Marzluff JM, Ewing K (2001) Restoration of fragmented landscapes for the conservation of birds: a general framework and specific recommendations for urbanizing landscapes. Restor Ecol 9:280-292. https://doi.org/10.1046/j.1526-100x.2001.009003280.x

Máthé O, Batáry P (2015) Insectivorous and open-cup nester bird species suffer the most from urbanization. Bird Study 62:78-86. https://doi. org/10.1080/00063657.2014.1000262

Mayorga I, Bichier P, Philpott SM (2020) Local and landscape drivers of bird abundance, species richness, and trait composition in urban agroecosystems. Urban Ecosyst 23:495-505. https://doi.org/10. 1007/s11252-020-00934-2

McKinney ML (2008) Effects of urbanization on species richness: a review of plants and animals. Urban Ecosyst 11:161-176. https:// doi.org/10.1007/s11252-007-0045-4

Meffert PJ, Dziock F (2013) The influence of urbanisation on diversity and trait composition of birds. Landsc Ecol 28:943-957. https://doi. org/10.1007/s10980-013-9867-z

Nielsen AB, Van den Bosch M, Maruthaveeran S, Van den Bosch CK (2014) Species richness in urban parks and its drivers: a review of empirical evidence. Urban Ecosyst 17:305-327. https://doi.org/10. 1007/s11252-013-0316-1

Oksanen J, Blanchet FG, Friendly M, Kindt R, Legendre P, McGinn D, Minchin PR, O'Hara RB, Simpson GL, Sólymos P, MHH S, Szoecs E, Wagner H (2018) Vegan: Community Ecology Package. R Package Version 25-3

Ortega-Álvarez R, MacGregor-Fors I (2009) Living in the big city: Effects of urban land-use on bird community structure, diversity, and composition. Landsc Urban Plan 90:189-195. https://oi.org/ 10.1016/j.landurbplan.2008.11.003

Paker Y, Yom-Tov Y, Alon-Mozes T, Barnea A (2014) The effect of plant richness and urban garden structure on bird species richness, diversity and community structure. Landsc Urban Plan 122:186195. https://doi.org/10.1016/j.landurbplan.2013.10.005

Palomino D, Carrascal LM (2006) Urban influence on birds at a regional scale: a case study with the avifauna of northern Madrid province. Landsc Urban Plan 77:276-290. https://doi.org/10.1016/j. landurbplan.2005.04.003

Parsons AW, Rota CT, Forrester T, Baker-Whatton MC, McShea WJ, Schuttler SG, Millspaugh JJ, Kays R (2019) Urbanization focuses 
carnivore activity in remaining natural habitats, increasing species interactions. J Appl Ecol 56:1894-1904. https://doi.org/10.1111/ 1365-2664.13385

Pennington DN, Hansel J, Blair RB (2008) The conservation value of urban riparian areas for landbirds during spring migration: land cover, scale, and vegetation effects. Biol Conserv 141:1235-1248. https://doi.org/10.1016/j.biocon.2008.02.021

Pinheiro J, Bates D, DebRoy S, Sarkar D (2018) nlme: Linear and nonlinear mixed effects models. R package version 3.1-137

Pirzio Biroli A, Van Doren BM, Grabowska-Zhang A (2020) Drivers of avian species richness and community structure in urban courtyard gardens. J Urban Ecol 6:juz026. https://doi.org/10.1093/jue/juz026

QGIS Development Team (2018) QGIS Geographic Information System. Open Source Geospatial Foundation Project. http://qgis.osgeo.org. Accessed 4 April 2019

Quesada J, MacGregor-Fors I (2010) Avian community responses to the establishment of small garden allotments within a Mediterranean habitat mosaic. Anim Biodivers Conserv 33:53-61

R Development Core Team (2018) A language and environment for statistical computing, Version 3.5.1. R Foundation for Statistical Computing, Vienna

Ricotta C, Moretti M (2011) CWM and Rao's quadratic diversity: a unified framework for functional ecology. Oecologia 167:181188. https://doi.org/10.1007/s00442-011-1965-5

Roberts DW (2016) labdsv: Ordination and multivariate analysis for ecology. R package version $1.8-0$

Sedláček O, Fuchs R, Exnerová A (2004) Redstart Phoenicurus phoenicurus and black redstart $P$. ochruros in a mosaic urban environment: neighbours or rivals? J Avian Biol 35:336-343. https://doi. org/10.1111/j.0908-8857.2004.03017.x

Seto KC, Güneralp B, Hutyra LR (2012) Global forecasts of urban expansion to 2030 and direct impacts on biodiversity and carbon pools. P Natl Acad Sci USA 109:16083-16088. https://doi.org/10.1073/ pnas.1211658109

Shwartz A, Shirley S, Kark S (2008) How do habitat variability and management regime shape the spatial heterogeneity of birds within a large Mediterranean urban park? Landsc Urban Plan 84:219-229. https://doi.org/10.1016/j.landurbplan.2007.08.003

Speak AF, Mizgajski A, Borysiak J (2015) Allotment gardens and parks: provision of ecosystem services with an emphasis on biodiversity. Urban For Urban Gree 14:772-781. https://doi.org/10.1016/j.ufug. 2015.07.007

Sudfeldt CF, Bairlein R, Dröschmeister C, König T, Langgemach T, Wahl J (2012) Vögel in Deutschland (Birds in Germany). DDA, BfN, LAG VSW, Münster

Szücs L, Jaszczak A (2013) Landscape values and functional changes of suburban areas: a case study of Göttingen (Germany). Acta Sci Pol 12:89-100

Taylor JJ, Lepczyk CA, Brown D (2016) Patch and matrix level influences on forest birds at the rural-urban interface. Landsc Ecol 31: 1005-1020. https://doi.org/10.1007/s10980-015-0310-5

Tryjanowski P, Morelli F, Mikula P, Krištín A, Indykiewicz P, Grzywaczewski G, Kronenberg J, Jerzak L (2017) Bird diversity in urban green space: A large-scale analysis of differences between parks and cemeteries in Central Europe. Urban For Urban Gree 27: 264-271. https://doi.org/10.1016/j.ufug.2017.08.014

United Nations (2014) World Urbanization Prospects: The 2014. revision. United Nations Department of Economic and Social Affairs, Population Division, New York. http://esa.un.org/unpd/wup/ publications/files/wup2014-highlights.pdf. Accessed 25 August 2019

United Nations (2018) About the Sustainable Development Goals. http:// www.un.org/sustainabledevelopment/sustainable-developmentgoals. Accessed 25 August 2019

von Post M, Smith HG (2015) Effects on rural House Sparrow and Tree Sparrow populations by experimental nest-site addition. J Ornithol 156:231-237. https://doi.org/10.1007/s10336-014-1117-x

Williams NS, Morgan JW, MJ MD, McCarthy MA (2005) Plant traits and local extinctions in natural grasslands along an urban-rural gradient. J Ecol 93:1203-1213. https://doi.org/10.1111/j.1365-2745. 2005.01039.x 